\title{
BASIC SCHOOL TEACHERS' FORMATIVE ASSESSMENT PRACTICES: INFLUENCE OF DEMOGRAPHIC VARIABLES
}

Eric ASARE 1

\begin{tabular}{|c|c|}
\hline Article Info & Abstract \\
\hline DOI:10.35452/caless.2021.3 & \multirow{10}{*}{$\begin{array}{l}\text { This study explored the influence of gender, grade level, and teaching } \\
\text { experience on the formative assessment practices of basic school } \\
\text { teachers in the Cape Coast Metropolis of Ghana. A total of } 300 \text { basic } \\
\text { teachers from the six (6) circuits in the Cape Coast Metropolis were } \\
\text { sampled using the multistage sampling procedure. A three-way } \\
\text { analysis of variance was used to test the hypothesis. The study results } \\
\text { revealed no statistically significant interaction effect for grade level, } \\
\text { gender, and teaching experience on the teachers' formative assessment } \\
\text { practices, F }(2,288)=2.087, p=0.126 \text {. A statistically significant main } \\
\text { effect for gender was found with small effect size, F }(1,288)=4.605 \text {, p= } \\
\text { 0.033. On the contrary, grade level and teachers' experience did not } \\
\text { influence basic school teachers' formative assessment practices in the } \\
\text { classroom. }\end{array}$} \\
\hline Keywords & \\
\hline Formative assessment & \\
\hline School-based assessment & \\
\hline Teachers & \\
\hline Practices & \\
\hline Demographic variables & \\
\hline Received: 04.12.2020 & \\
\hline Accepted: 31.03 .2021 & \\
\hline Published: 27.06.2021 & \\
\hline
\end{tabular}

Cited as APA: Asare, E. (2021). Basic school teachers' formative assessment practices: Influence of demographic variables. International Journal of Current Approaches in Language, Education and Social Sciences (CALESS), 3 (1), 57-68.

\section{Introduction}

A classroom is composed of students with diverse needs, backgrounds, and skills, hence the assessment strategies employed by teachers in the classroom are critical. The type of assessment strategy a teacher employs in his/her classroom can have an enormous consequence on students' intrinsic interest and attitude to learn (Clarke et al., 2003). According to Looney et al. (2017), the right choice of classroom assessment method allows teachers to identify challenges confronted by students in reaching desirable learning outcomes, and in formulating appropriate remedial measures to redress the situation. In other words, teachers are the core implementers of any approach in the classroom, and the assessment practices they engage in influence learning in the classroom. There is a shift in views towards the use of assessments as tools to enhance deep learning (Shepard, 2000). As the Ghanaian educational sector

\footnotetext{
1 West African Examinations Council, Records and Aptitude Tests Department, Ghana, asareeric12@gmail.com
} 
moves from the focus on cumulative or summative evaluation, particularly at the basic level of education, to ensure that all learn to a specified standard as enshrined in the National Pre-tertiary Education Curriculum (MoE, 2018), the practice of formative assessment has become a necessary activity to achieving this goal. In the process of achieving this goal, instructional management decisions role of classroom assessment in Ghanaian classrooms would be achieved to its maximum.

Taylor (2017) defines formative assessment as the feedback from learners used to promote learning and that it is a method of providing a clear image of where learners need to reach their goals in learning. Formative assessment is entrenched in the teaching and learning process, which is used to adjust the teaching strategies or techniques to meet educational needs and standards (Rivai et al., 2019). To Anwar (2019), formative assessments are considered a means of ensuring deeper learning and understanding. They provide feedback that moves learners forward, activating students as instructional resources for one another. Similarly, Widiastuti et al. (2020) also agree to the fact that the central focus of this type of assessment, is to detect the challenges students encounter in learning and assist them to advance their knowledge and skills. Consequently, teachers are encouraged to make and give appropriate types of assessments to measure students' competence. Several studies (e.g., Dix, 2017; Gloria et al., 2018; Hattie, 2012; Looney et al., 2017; Ozan \& Kincal, 2018) have documented the contributions of formative assessment in improving students' achievement and reducing the achievement gap among students. For instance, Hattie's (2012) study revealed that formative assessment had a visible effect on students' achievement. Similarly, Gloria et al. (2018) discovered that formative assessment has a significant and positive impact on learners' motivation and achievement, problemsolving skills, independent and creative thinking, perseverance in learning, listening with understanding, and empathy. In a mixed-method study on the effects of formative assessment on academic achievement, attitude towards the lessons, and selfregulation skills, it was discovered that the experimental group had significantly higher academic achievement levels and better attitudes towards the class than the students in the control group. It was further revealed that formative assessment had a positive effect on students' self-regulation skills (Ozan \& Kincal, 2018).

The Assessment for Achievement and Improvement through Assessment (AAIA, 2003) holds that teachers must provide a classroom environment that is safe and secure and is favourable for effective learning. For students to learn, the fear of failure has to be removed to encourage honesty and openness. Moreover, students must be provided with support, by being able to try out techniques in a safe and secure place. 
Leahy et al. (2005) highlighted five non-negotiable elements for successful use of formative assessment in schools: clarifying and sharing learning intentions and criteria for success; engineering effective classroom discussions and learning tasks; providing feedback that moves learners forward; activating students as the owners of their learning, and activating students as instructional resources for one another. Many authors of classroom assessment have identified oral questioning, group tasks, projects, exercises, assignments, presentations, discussions, quizzes, and individual tasks as some of the forms or types of formative assessment practices in the classroom (Asare, 2020; Cummins \& Davesne, 2009; Akyina \& Oduro-Okyireh, 2019; Orlich et al., 2004).

Literature confirms that it is important to know how key demographic variables including gender, grade level, and teaching experience influence teachers' assessment practices (e.g., Duncan \& Noonan, 2007). Bernhardt (1998) maintains that these teacher demographic variables are essential for us to appreciate the outcomes of all fragments of our educational structure as they aid us to detect trends and garner evidence for purpose of prediction and planning. Concerning the influence of gender on assessment practices, previous studies have generated mixed findings. For instance, Yusuf's (2015) study on teachers' classroom assessment strategies in Nigerian secondary schools revealed no statistically significant differences. Equally, Alsarimi's (2000) work on classroom assessment practices in the Sultanate of Oman also discovered no statistically significant differences. However, Alkharusi et al's. (2014) study on the educational assessment profile of teachers reported significant differences. Similarly, Alkharusi et al. (2012) and Mertler (1998) reported significant differences. In terms of grade level, Alkharusi's (2011) work on teachers' classroom assessment skills revealed significant differences. Likewise, Mertler's (1998) study on classroom assessment practices of Ohio teachers reported significant differences. Conversely, Cizek et al. (1995) reported no significant differences.

Regarding teaching experience, Yusuf (2015) and Alsarimi (2000) reported no significant differences, however, Mertler (1998) and Alkharusi (2011) reported significant differences. The aforementioned studies tend to confirm that the influence of gender, grade level, and teaching experience may be unique regarding the study sample, and geographical location. These aforesaid studies were conducted in other countries, consequently, there is the need to investigate the influence of gender, grade level, and teaching experience on teachers' formative assessment practices in the Ghanaian context. 
In literature, that is in the Ghanaian context, a lot of studies have been conducted on formative assessment at various levels of education (Akyina \& Oduro-Okyireh, 2019; Amoako et al., 2019; Asare, 2020; Bekoe et al., 2013; Oduro, 2015). However, these studies have failed to investigate the influence of key demographic variables such as gender, grade level, and teaching experience on teachers' formative assessment practices. There is, therefore a gap in the literature that needs to be filled. It is against this backdrop that this study sought to investigate the influence of gender, grade level, teaching experience, and their various interactions on teachers' formative assessment practices, particularly at the basic level. This is because the basic level seeks to lay a strong foundation for inquiry, creativity and innovation, and lifelong learning in general, and provides building blocks for higher levels of education. Findings from this study would provide teachers and researchers with a better understanding of variables related to teachers' formative assessment practices. Also, findings would enable policymakers (Ministry of Education), the Ghana Education Service (GES), and the Directorates of Education in the various regions to close gaps in the practice of formative assessment in the classroom. Lastly, discoveries from this current study would contribute circumstantial data on the impact of key teacher demographic variables on formative assessment practices of basic teachers to the field of classroom assessment that is, to both local and international literature. The study's research hypothesis was that teachers' gender, grade level, teaching experience, and their various interactions would have no statistically significant influence on teachers' formative assessment practices.

\section{Method}

\subsection{Design and Participants}

This study employed a descriptive survey research design. The choice of this design offered sufficient opportunity for the sample to obtain spontaneous reactions for the interpretation and analysis of the phenomenon relevant to the focus of this study (Abdulkareem Bibire, 2020). The target population for this study consisted of 1,006 public basic school teachers (that is Primary and Junior High School teachers) in the Cape Coast Metropolis of Ghana, except for teachers in special schools. A multistage sampling procedure was used to attain the sample for the study. Initially, the cluster sampling technique was used to classify the schools into six (6) clusters namely; Cape Coast, Aboom, Bakaano, Ola, Pedu/Abura, and Efutu. In the subsequent stage, the simple random sampling technique was utilized to choose sixty-one (61) schools from the six (6) circuits. The proportional stratified sampling technique was then employed to acquire a proportionate number of respondents based on gender in each of the 
circuits. Finally, the simple random sampling technique was utilized to choose the subjects in the selected schools.

Consequentially, 300 teachers represented the sample for the study. The sample size was obtained in accordance with Krejcie and Morgan's (1970) table for sample size determination. It was supported by Ogah's (2013) proposition that, conducting a study with a population of 1,100, a sample size of 285 is appropriate for the generalizability of the results. However, the sample size was increased to 300 participants to enhance the practicability of the theoretical sample size. This included 111 (37\%) male and 189 $(63 \%)$ female teachers from the six (6) circuits in the Cape Coast Metropolis. Regarding grade level, 141 (47\%) represented Primary teachers and 159 (53\%) represented Junior High teachers. Concerning teaching experience, 51 (17\%) teachers had no more than 5 years of teaching experience, 84 (28\%) had 6-10 years of teaching experience, and 165 (55\%) were experienced teachers with more than 11 years of experience (Asare, 2020). These groupings were done based on previously discussed literature (Alkharusi, 2011; Yusuf, 2015).

\subsection{Data Collection Instrument and Analysis}

The instrument for the study was a questionnaire. It was adapted from Akyina \& Oduro-Okyireh (2019). The instrument contained 13 items on formative assessment practices and was measured on a four-point Likert scale. The measurement was specified as follows: Always, Very Often, Sometimes, and Never. A pre-test of the instrument was done using 50 teachers in the Komenda Edina Eguafo Abirem (KEEA) Municipality since they share similar characteristics with teachers in the Cape Coast Metropolis. The instrument produced a reliability coefficient of 0.87 using Omega, and 0.87 using Cronbach's Alpha. This conforms with Kline's (2016) recommendation that a reliability coefficient of about 0.80 is very good.

\subsection{Data Collection Procedure}

Ethical clearance was acquired from the Institutional Review Board of the University of Cape Coast before the data collection. The researcher gained authorization from the Headteachers/masters whose teachers were chosen for the study a week before administering the questionnaire. On the data collection day, the purpose of the study and procedure for responding to the questionnaire was explained to the respondents. They were also informed about the voluntary nature of the study. Moreover, informed consent from participants was sought before the questionnaire was administered. 


\section{Findings}

3.1. Hypothesis: There is no statistically significant influence of gender, grade level, teaching experience, and their various interactions on basic teachers' formative assessment practices.

In testing the hypothesis, a three-way ANOVA was used with the aid of SPSS V. 23. This was because the study involved three independent groups that are with $2 \times 2 \times 3$ levels for grade level, gender, and teaching experience respectively. The responses were on the interval scale which ranged from Never (1), Sometimes (2), Very often (3), to Always (4). Denis (2016), Tabachnick and Fidell (2001 as cited in Pallant, 2005), and Tabachnick and Fidell (2007, p. 80) advise inspecting the shape of the distribution instead of using formal inference tests (e.g., using a histogram and Q-Q plots) for normality when working with large samples, that is 200 and above. Consequently, a visual inspection of the normal probability plots (Normal Q-Q Plots), and the shape of the histograms for the three independent groups revealed that distributions were approximately normal. Besides, the skewness and kurtosis values were between the range of -2 and +2 indicating that the distributions were reasonably normal (Keenan \& James, 2016, p. 228). A preliminary analysis to test the assumption of Homogeneity of Variance was conducted using Levene's test. The $p$-value for the Levene's test was .55, which is greater than the alpha (critical value) of .05, $F(11,288)=0.889, p=0.551$. This implies that the assumption of homogeneity has been met for this sample, therefore, equal variance is assumed.

Table 1. Tests of Between-Subjects Effects

\begin{tabular}{|c|c|c|c|c|c|c|}
\hline Source & $\begin{array}{c}\text { Type III Sum } \\
\text { of Squares }\end{array}$ & $\mathrm{df}$ & $\begin{array}{l}\text { Mean } \\
\text { Square }\end{array}$ & $\mathrm{F}$ & Sig. & $\begin{array}{c}\text { Partial } \\
\text { Eta } \\
\text { Squared }\end{array}$ \\
\hline Corrected Model & $473.124^{a}$ & 11 & 43.011 & 1.571 & .107 & .057 \\
\hline Intercept & 295647.691 & 1 & 295647.691 & 10799.542 & .000 & .974 \\
\hline demo1 & 53.414 & 1 & 53.414 & 1.951 & .164 & .007 \\
\hline demo2 & 126.074 & 1 & 126.074 & 4.605 & .033 & .016 \\
\hline demo3 & 61.382 & 2 & 30.691 & 1.121 & .327 & .008 \\
\hline demo1* demo2 & 41.357 & 1 & 41.357 & 1.511 & .220 & .005 \\
\hline demo1* demo3 & 50.565 & 2 & 25.283 & .924 & .398 & .006 \\
\hline demo $2 *$ demo 3 & 75.744 & 2 & 37.872 & 1.383 & .252 & .010 \\
\hline demo $1^{*}$ demo $2^{*}$ demo3 & 114.247 & 2 & 57.124 & 2.087 & .126 & .014 \\
\hline Error & 7884.273 & 288 & 27.376 & & & \\
\hline Total & 517507.000 & 300 & & & & \\
\hline Corrected Total & 8357.397 & 299 & & & & \\
\hline
\end{tabular}


Table 2. Descriptives

\begin{tabular}{lllll}
\hline & \multicolumn{3}{c}{} & $95 \%$ Confidence Interval \\
\hline Gender & Mean & Std. Error & Lower Bound & Upper Bound \\
Male & 40.508 & .574 & 39.379 & 41.637 \\
Female & 42.216 & .552 & 41.130 & 43.302 \\
\hline
\end{tabular}

As shown in Table 1, the main effect of gender was statistically significant at $p<0.05$, whilst grade level and teaching experience were not statistically significant. Comparison of the mean usage (Table 2) for the gender group suggests that female basic teachers had slightly higher usage of formative assessment than the male teachers. The main effect of gender yielded an effect size of 0.016 , indicating that $1.6 \%$ of the variance in teachers' formative assessment practices was explained by gender, $F(1,288)=4.605, p=0.033$. The effect size was small based on Cohen's (1988) criterion. The interaction effect was not statistically significant, $F(2,288)=2.087, p=0.126$, indicating that there was no combined effect for grade level, gender, and teaching experience on the teachers' formative assessment practices.

\section{Conclusion, Discussion and Suggestions}

A three-way ANOVA was performed to investigate the influence of gender, grade level, teaching experience, and their various interactions on basic teachers' formative assessment practices in the Cape Coast Metropolis of the Central Region of Ghana. The study revealed no combined effect for grade level, gender, and teaching experience on basic teachers' formative assessment practices. However, there was a statistically significant main effect in the formative assessment strategies used by the male and female teachers. The result of the study aligns with the findings of Alkharusi et al. (2012, 2014) and Mertler (1998) who reported gender differences with regard to teachers' assessment practices. Nevertheless, the current study finding is inconsistent with the finding of Yusuf's (2015) work on teachers' classroom assessment strategies in Nigeria, which revealed no significant difference in terms of gender. In the same vein, Alkarusi (2011) and Alsarimi (2000) also reported no significant difference in assessment practices with respect to gender.

Concerning grade level, the study revealed no statistically significant difference in formative assessment strategies usage by Primary and Junior High basic school teachers. This finding conforms with that of Cizek et al. (1995) who found no significant grade level differences. However, Alkarusi (2011) and Mertler (1998) 
discovered significant differences among teachers at different school levels regarding their assessment practices.

Apropos the impact of teachers' experience on their practice of formative assessment, the study discovered no statistically significant difference between the three experience groups that is; ' $1-5$ ', ' $6-10$ ', and ' 11 and above'. The finding of the current study is in tandem with the findings of Yusuf (2015) and Alsarimi (2000). However, the finding is in contrast with Mertler (1998) and Alkarusi (2011) who reported significant differences based on teachers' years of teaching experience concerning their use of alternative assessment. A probable justification for this outcome in the current study might be that teachers are responding to the call to practice formative assessment in their respective classrooms as documented in the National Pre-tertiary Education Curriculum. Another reason could be that capacity-building workshops carried out by the Ghana Education Service, and Cape Coast Metropolitan Directorate of Education are having an equal impact on teachers' practice of formative assessment in the classroom irrespective of their teaching experience.

Based on research findings described above, the study can conclude that grade level, gender, and teaching experience had no interaction effect on basic teachers' formative assessment practices. Gender had a significant main effect on teachers' formative assessment practices. Besides, teachers' experience or years of teaching, and grade level did not influence their formative assessment practices in the classroom. In other to close the gender gap, the researcher recommends a continued organization of workshops and seminars for basic teachers especially male teachers to motivate them to practice more formative assessment in their classrooms. This leads to teachers' professional development in addition to students learning through the transference of skills and expertise acquired to the lesson plans. Also, circuit supervisors should ensure that teachers in the various schools are engaging in the practice of the formative component of the School-Based Assessment as documented in the new curriculum. Future studies might consider collecting objective measures of teachers' practices that are free from the response-biases associated with self-report measures. Additionally, the current study was undertaken in public basic schools, future studies could examine the influence of these variables, or other variables that influence teachers' practice of formative assessment in private basic schools, as well as secondary, and tertiary levels of education.

\section{Disclosure statement}

No potential conflict of interest was reported by the author 


\section{References}

Abdulkareem Bibire, H. (2020). Effects of social networking sites usage on psychological well- being of undergraduates in Nigerian universities. International Journal of Social Sciences and Education Research, 6(4), 460-471. https://doi.org/10.24289/ijsser.776624

Akyina, O. K., \& Oduro-Okyireh, G. (2019). Formative assessment practices of senior high school teachers in the Ashanti Mampong Municipality of Ghana. British Journal of Education, 3(7), 27-38. https://bit.ly/3neoxle

Alkharusi, H., Aldhafri, S., Alnabhani, H., \& Alkalbani, M. (2014). Educational assessment profile of teachers in the Sultanate of Oman. International Education Studies, 7(5), 116 -137. https://doi.org/10.5539/ies.v7n5p116

Alkharusi, H. (2011). Teachers' classroom assessment skills: Influence of gender, subject area, grade level, teaching experience, and in-service assessment training. Journal of Turkish Science Education, 8, 39-48. http://www.tused.org/index.php/tused/article/view/358

Alkharusi, H., Aldhafri, S., Alnabhani, H., \& Alkalbani, M. (2012). Educational assessment attitudes, competence, knowledge, and practices: An exploratory study of Muscat teachers in the Sultanate of Oman. Journal of Education and Learning, 1, 217232. https://doi.org/10.5539/jel.v1n2p217

Alsarimi, A. M. (2000). Classroom assessment and grading practices in the Sultanate of Oman. [Unpublished doctoral dissertation]. University of Pittsburgh.

Amoako, I., Asamoah D., Bortey, J. (2019). Knowledge of formative assessment practices among senior high school mathematics teachers in Ghana. American Journal of Humanities and Social Sciences Research, 3(3), 8-13. https://bit.ly/3xnOgw0

Anwar, S. (2019). Formative assessment tool for active learning. European Journal of Biomedical and Pharmaceutical sciences, 6(1), 480-485. https://cutt.ly/LvMf7Fh

Asare, E. (2020). Basic teachers' perceptions and practices of formative assessment in the Cape Coast Metropolis of Ghana. Journal of Applied Educational and Policy Research, 5(1), 178-187. https://journals.uncc.edu/jaepr/article/view/1053

Assessment for Achievement and Improvement through Assessment. (2003). Pupil selfassessment. Suffolk Design and Print. 
Bekoe, S. O., Eshun, I., \& Bordoh, A. (2013). Formative assessment techniques tutors use to assess teacher trainees learning in social studies in colleges of education in

Ghana. Journal of Research on Humanities and Social Sciences, 3(4), 20-30. https://www.iiste.org/Journals/index.php/RHSS/article/view/4941

Bernhardt, V. L., (1998, March). Invited Monograph No. 4. CASCD.

https://nces.ed.gov/pubs2007/curriculum/pdf/multiple measures.pdf

Clarke, S., Timperley, H., \& Hattie, J. (2003). Unlocking formative assessment. Routledge Falmer.

Cizek, G. J., Fitzgerald, S. M., \& Rachor, R. E. (1995). Teachers' assessment practices: Preparation, isolation and the kitchen sink. Educational Measurement, 3(2).doi.org/10.1 207/s153677ea0302 3

Cohen, J. (1988). Statistical power analysis for the behavioral sciences. Erlbaum.

Cummins, P. W., \& Davesne, C. (2009). Using electronic portfolios for second language assessment. The Modern Language Journal, 93(1), 848-867. https://doi.org/10.1111/j.1540$\underline{4781.2009 .00977 . x}$

Denis, J. D. (2016). Applied univarıate, bivarnate, and multivarıate statistics. John Wiley \& Sons.

Dix, S. (2017). The effectiveness of formative assessment. Teachers and Curriculum, 6(1), 29-34. doi.org/10.15663/tandc.v6i1.202

Duncan, C. R., \& Noonan, B. (2007). Factors affecting teachers' grading and assessment practices. Alberta Journal of Educational Research, 53(1), 1-21. https://cutt.ly/QvMgU1J

Gloria, Y., Sudarmin, S., Wiyanto, \& Indriyanti, D. R. (2018). The effectiveness of formative assessment with understanding by design (UBD) stages in forming habits of mind in prospective teachers. Journal of Physics: Conference Series. http://ww w.researchgate.net.

Hattie, J. (2012). Visible learning for teachers: Maximizing impact on learning. Routledge.

Keenan, A. P., \& James, P. S. (2016). Applied multivariate statistics for the social sciences analyses with SAS and IBM's SPSS (6th ed.). Taylor \& Francis Group.

Kline, R. B. (2016). Principles and practice of structural equation modeling (4th ed.). The Guilford Press.

Krejcie, R. V., \& Morgan, D. W. (1970). Determining sample size for research activities. Educational and Psychological Measurement, 30, 607-610. https://doi.org/10.1177/001316447003000308 
Leahy, S., Lyon, C., Thompson, M., \& Wiliam, D. (2005). Classroom assessment: Minute by minute, day by day. Educational Leadership, 63(3), 19-24. https://cutt.ly/GvMhbmE

Looney, A., Cumming, J., van Der Kleij, F., \& Harris, K. (2017). Reconceptualising the role of teachers as assessors: Teacher assessment identity. Assessment in Education: Principles, Policy E Practice, 1-26. https://doi.org/10.1080/0969594X.2016.1268090

Mertler, C. A. (1998). Classroom assessment practices of Ohio teachers. Conference paper: EDRS.

Ministry of Education. (2018). National pre-tertiary education curriculum framework.

Oduro, O. E. (2015). Assessment in mathematics classroom in Ghana: A study of teachers' practices. University of Sussex. http://www.sro.sro.sussex.ac.uk.

Ogah, J. K. (2013). Decision making in the research process: Companion to students and beginning researchers. Adwinsa Publications.

Orlich, D. C., Harder, R. J., Callahan, R. C, Trevisan, M. S., \& Brown, A. H. (2004). Teaching strategies: A guide to effective instruction. Houghton Mifflin Company.

Ozan, C., \& Kincal, R. Y. (2018). The effects of formative assessment on academic achievement, attitudes toward the lesson, and self-regulation skills. Educational Sciences: Theory E Practice, 18, 85-118. dx.doi.org/10.12738/estp.2018.1.0216

Pallant, J. (2005). SPSS survival manual: A step by step guide to data analysis using SPSS for Windows (Version 12). Allen \& Unwin.

Rivai, E., Ridwan, A., Supriyati, Y., \& Rahmawati, Y. (2019). Influence of test construction knowledge, teaching material and attitude on sociological subject to quality of objective test in public and private vocational schools.

International Journal of Instruction, 12(3), 497-

512. https://doi.org/10.29333/iji.2019.1233a .

Shepard, L. A. (2000). The role of classroom assessment in teaching and learning. Center for the Study of Evaluation (CSE Technical Report \# 517), University of California.

Tabachnick, B. G., \& Fidell, L. S. (2007). Using multivariate statistics (5th ed.). Allyn \& Bacon.

Taylor, M. A. (2017). Formative for whom? How formative assessment is used in the english classroom of an upper secondary school in Sweden. [Degree Project, Umeå University]. http://www.divaportal.org/smash/get/diva2:1119600/FULLTEXT0 1.pdf 
Widiastuti, I. A. M. S., Mukminatien, N., Prayogo, J. A., \& Irawati, E. (2020). Dissonances between teachers' beliefs and practices of formative assessment in EFL classes. International Journal of Instruction, 13(1), 71-

84. https://doi.org/10.2933/Iji.2020.1315a

Yusuf, H. T. (2015). Teachers' classroom assessment strategies and curriculum implementation in Nigerian secondary schools. Malaysian Online Journal of Educational Management (MOJEM), 3(4), 50-62. https://mojem.um.edu.my/article/view/6079 